\title{
The Clusters Self-Assembled Crystal and Magnetic Structure During the Martensite Transition in Fe86mn13c Alloy
}

\author{
Ludmila I. Kveglis ${ }^{\mathrm{a}, \mathrm{e}}$, \\ Alexey V. Dzhes', Micail N. Volochaev ${ }^{\mathrm{c}}$, \\ Alexander G. Cherkov ${ }^{d}$ and Fedor M. Noskova* \\ ${ }^{a}$ Siberian Federal University \\ 79 Svobodny, Krasnoyarsk, 660041, Russia \\ ${ }^{b}$ East Kazakhstan State Technical University \\ 69 A.K. Protozanov, Ust-Kamenogorsk, 070004, \\ The Republic of Kazakhstan \\ ${ }^{c}$ Kirensky Institute of Physics \\ 50/38 Akademgorodok, Krasnoyarsk, 660036, Russia \\ ${ }^{d}$ Novosibirsk State University \\ 2 Pirogov, Novosibirsk, 630090, Russia \\ ${ }^{e}$ East Kazakhstan State University \\ 55 Kazakhstan, Ust-Kamenogorsk, 070004, \\ The Republic of Kazakhstan
}

In bulk and thin film state Fe86Mn13C alloy observed experimentally self-assembly of the crystal and magnetic structures on multiscale levels. Offered self-assembly cluster model of atomic structure based on the concept of a liquid-like state of the material in localized areas, formed in the waves of plastic deformation.

Keywords: Thin magnetic films, Fe86Mn13C alloy, close packed structure clusters, magnetic structure, martensite transitions, density of electronic states, waves of plastic deformation.

(C) Siberian Federal University. All rights reserved

* Corresponding author E-mail address: yesoono@yandex.ru 


\title{
Кластерная самоорганизация
}

\section{кристаллической и магнитной структур}

\section{в процессе мартенситного превращения в сплаве $\mathrm{Fe}_{86} \mathrm{Mn}_{13} \mathrm{C}$}

\author{
Л.И. Квеглис ${ }^{\mathrm{a}, \boldsymbol{д}}$, А.В. Джес \\ М.Н. Волочаев ${ }^{\text {, }, ~ А . Г . ~ Ч е р к о в ~}{ }^{\mathrm{r}}$, Ф.М. Носков ${ }^{\mathrm{a}}$ \\ ${ }^{a}$ Сибирский федеральный университет \\ Россия, 660041, Красноярск, Свободный, 79 \\ ${ }^{\sigma}$ Восточно-Казахстанский \\ государственный технический университет \\ Республика Казахстан, 070004 \\ Усть-Каменогорск, Протозанова А.К., 69 \\ ${ }^{8}$ Институт физики им. Л.И. Киренского СО РАН \\ Россия, 660036, Красноярск, Академгородок, 50, стр. 38 \\ ${ }^{2}$ Новосибирский государственный университет \\ Россия, 630090, Новосибирск, ул. Пирогова, 2 \\ ${ }^{\circ}$ Восточно-Казахстанский государственный университет \\ Республика Казахстан, 070004 \\ Усть-Каменогорск, Казахстанская, 55
}

В массивных и тонкопленочных образиах сплава $\mathrm{Fe}_{86} \mathrm{Mn}_{13} \mathrm{C}$ экспериментально наблюдается самоорганизация кристаллической и магнитной структур на разномасштабных уровнях. Предлагается кластерная модель атомной самоорганизации, основанная на концепции жидкоподобного состояния материала в локальных участках, образованных волнами пластической деформачии.

Ключевые слова: тонкие магнитные пленки, сплав $\mathrm{Fe}_{86} \mathrm{Mn}_{13} \mathrm{C}$, кластеры с плотноупакованной структурой, магнитная структура, мартенситные превращения, плотность электронных состояний, волны пластической деформачии.

\section{Introduction}

The $\mathrm{Fe}_{86} \mathrm{Mn}_{13} \mathrm{C}$ alloy is widely used in engineering as a self-strengthening material under the influence of shock loading and it has shape memory effect. Fe-Mn films are investigated as materials for spintronics due to their unique properties [1]. First the most fundamental work devoted to the synergistic mechanism of deformation of a solid state under the influence of external loads is to work [2]. One of the first works devoted to the problem of self-assembly of magnetic domain structure was the work [3]. In thin film technology the pressure at the interface between the film and the substratecan be up to $7 \mathrm{Gpa}$ due to differences in thermal expansion coefficients and nonlinear effects.

The results of studies on the structure, phase composition and magnetic structure of thin films of magnetic alloy $\mathrm{Fe}_{86} \mathrm{Mn}_{13} \mathrm{C}$, obtained under different conditions are presented. The methods of transmission electron microscopy techniques including Lorentz microscopy were used.

In the alloy $\mathrm{Fe}_{86} \mathrm{Mn}_{13} \mathrm{C}$ previously discovered the thermoelectric effect [4]. The thermoelectromotive force and magnetoresistance in Fe86Mn13C alloy reverses its sign in a certain range of temperatures. Modulated structure - antiferromagnetic austenite and ferromagnetic deformation martensite formed 
in conditions of plastic deformation of the alloy $\mathrm{Fe}_{86} \mathrm{Mn}_{13} \mathrm{C}$. This particularity creates a unique electrical and magnetic properties of the alloy $[4,5]$. In this regard, thin films $\mathrm{Fe}_{86} \mathrm{Mn}_{13} \mathrm{C}$, having a modulated structure, can be used as a spintronic material [6].

The aim of this work is examination of the crystal and magnetic structure for the bulk, thining foil and thin film states of this alloy, subjected to plastic deformation leads to martensite transition.

\section{Research methods}

$\mathrm{Fe}_{86} \mathrm{Mn}_{13} \mathrm{C}$ films were obtained on glass and $\mathrm{NaCl}$ substrates by thermal vacuum evaporation at a pressure of $10^{-5}$ Torr using a VUP-4 installation. The thin-film samples then underwent cryomachining, i.e. repeated immersion in liquid nitrogen with intermediate endurance at room temperature for several minutes. Since thermal expansion coefficients of the film and the substrate differed several times from glass $\mathrm{NaCl}, \mathrm{MgO}$ the film sample was tested under an effective loading of about $7 \mathrm{Gpa}$. The structure and magnetic contrast of the films were investigated using EM-200 and JEM-2100 transmission electron microscopy, including Lorentz electron microscopy and electron diffaction techniques. High resolution electron microscopy methods for investigation of atomic and magnetic structures in Fe86Mn13C thin films. The films were prepared at different substrate temperatures: room temperature $\left(25^{\circ} \mathrm{C}\right)$ and $200{ }^{\circ} \mathrm{C}, 300^{\circ} \mathrm{C}$ and $400^{\circ} \mathrm{C}$. At each temperature of substrate the evaporation was carried out with different time: short time $(\sim 7.5 \mathrm{~s})$ and long time $(\sim 30-40 \mathrm{~s})$. Spin polarized density of electronic states for clusters FK12, FK14, FK16 simulated by the method of Slater theory of the scattered waves for comparing the energy of the optical transitions with energy obtained from the calculation of the spin-polarized electron density of states for FK12 and FK16. The optical properties were investigated on adsorption spectrometer Shimadzu UV 3600.

\section{Experemental results and discussion}

We explain features of thermoelectrisity and magnetoresistivity in terms of coexistence of heterogeneous crystalline and magnetic structures in the samples Fe86Mn13C alloy. At the Fig. 1 dark strings correspond to deformation martensite in initial austenite phase (light areas). Similar striped structure was observed on bulk samples in work [4] of the alloy in the period between the stripes was a few microns.

Fig. 2,a b, c, shows electron microscope image of a magnetic contrast from the alloy films $\mathrm{Fe}_{86} \mathrm{Mn}_{13} \mathrm{C}$, obtained with the different substrate temperature. The magnetic structure in Fig. 2,a is bubble, magnetic structure at Fig. 2,b is predominantly "a stripe" character. The magnetic structure at Fig. 2,c is vortex.

Electron diffraction patterns Fig. 2,d indicate the presence of the bcc phase in addition to the quasicrystalline inclusions, which is typical for structures Frank-Kasper FK-12 + FK-16 [7].

Under such conditions, the deposition film structure appears Frank-Kasper type FK16. This structure was detected by electron diffraction pattern decoding.

At the Fig. 3 a,b the resultes of clusters modeling Frank-Kasper structures FK16 and FK12 are represented. Polyhedrons with 16 vertices and 12 vertices are connected by triangular faces.

We previously observed structure of the type FK12+FK16 for thinning foils alloy $\mathrm{Fe}_{86} \mathrm{Mn}_{13} \mathrm{C}$ by $\mathrm{X}$-ray diffraction method. Fig. 3,c shows this picture. We used for comparison, the X-ray diffraction pattern having a structure FK16+FK12. This picture represented at Fig. 3,d. 


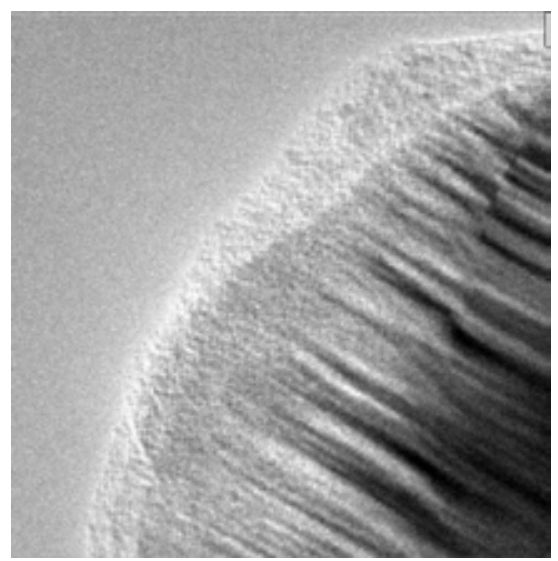

a

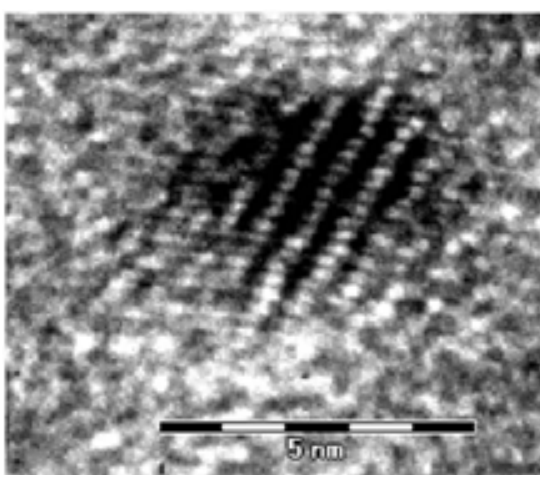

b

Fig. 1. High resolution electron microscopy image of microstructure $\mathrm{Fe}_{86} \mathrm{Mn}_{13} \mathrm{C}$ alloy after loading in liquid nitrogen each dark region is magnetic martensite phase: $a$ - thinning foil; $b$ - thin film
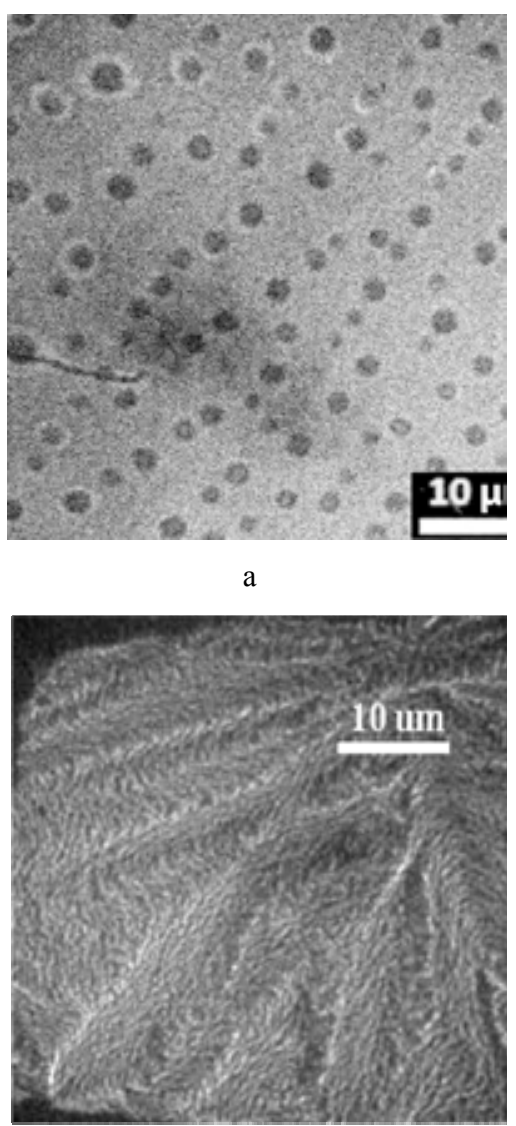

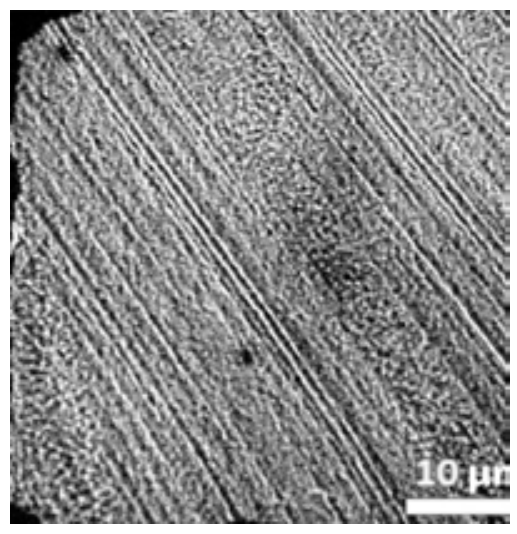

b

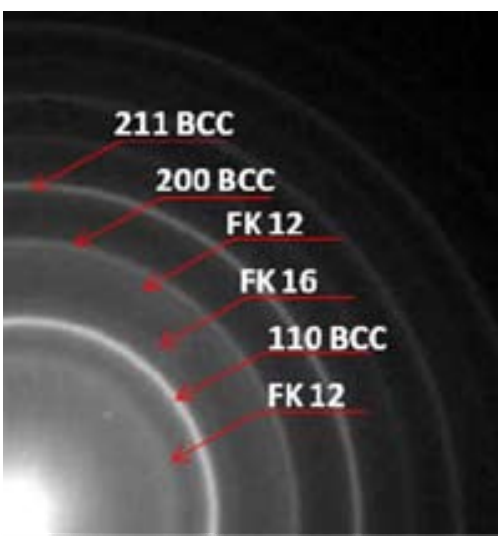

d

Fig. 2. The Lorentz electron microscopy images of domain structures Fe86Mn13C films obtained at different temperatures of substrates: $\mathrm{a}-200{ }^{\circ} \mathrm{C} ; \mathrm{b}-300^{\circ} \mathrm{C} ; \mathrm{c}-400{ }^{\circ} \mathrm{C} ; \mathrm{d}$ - the picture of electrons diffraction for $400{ }^{\circ} \mathrm{C}$ 

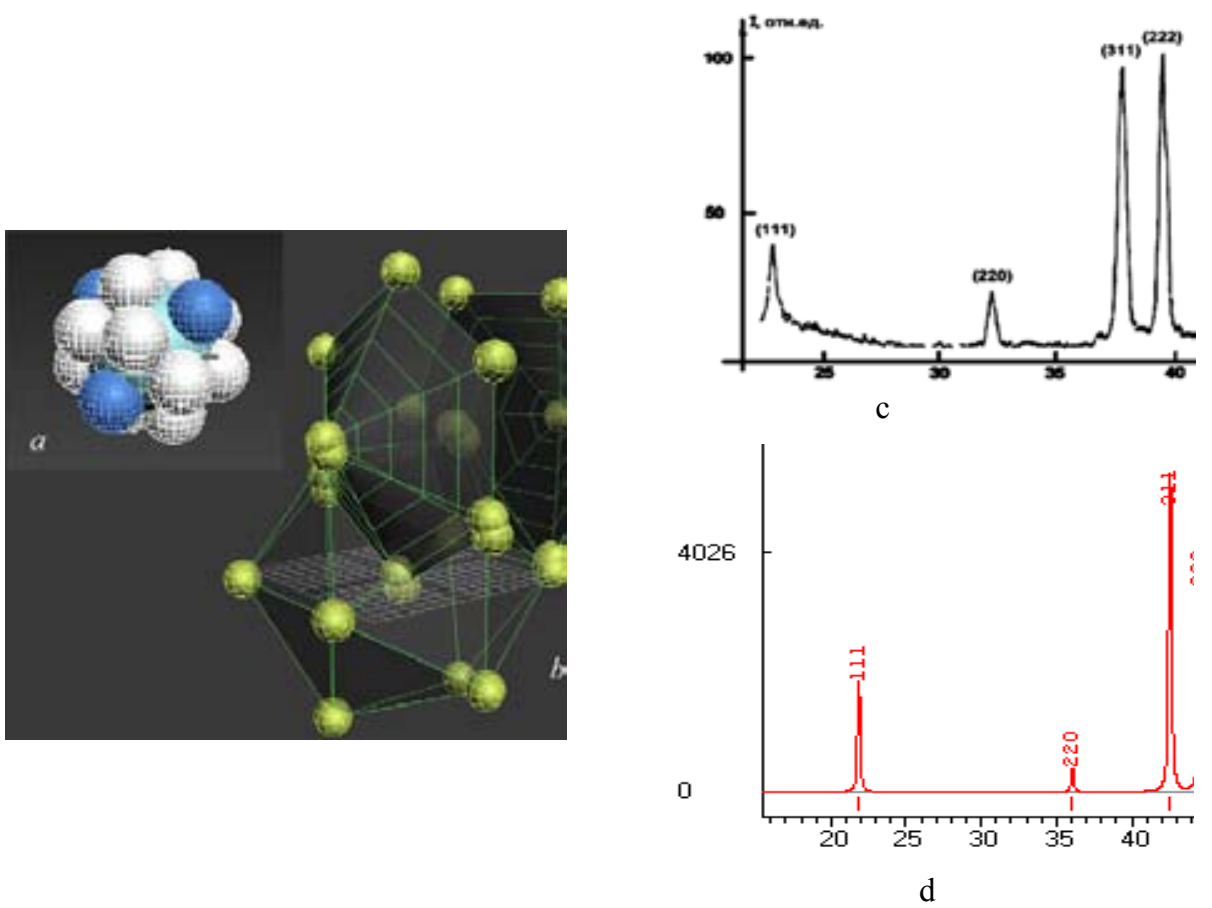

Fig. 3. The structures of Frank-Kasper FK 16 and FK12: a - the model of cluster FK 16; b - Frank-Kasper structures $\mathrm{MgCu}_{2}$ (FK 16 + FK12); c - X-ray diffraction spectra from thinning foil Fe86Mn13C alloy; d - X-ray diffraction spectra for the structure $\mathrm{MgCu} 2$, consist of clusters FK 16 and FK 12

According to works of V.E. Panin [8] nucleation phase and martensite deformation in alloys occurs at deformation defects. The author describes a deformable solid as a multilevel nonlinear hierarchically organized system. Considered highly excited structural states, among which in a deformed crystal are allowed new structural condition. Changing the interatomic distance causes the occurrence of the bifurcation of the potential minima of the particles.

With increasing degree of plastic deformation, the translational invariance of the crystal decreases progressively [8]. The curve of the nonequilibrium thermodynamic Gibbs potential on the molar volume (Fig. 4,a) each type of defect deformation as soliton curvature certain scale level, characterized by a local minimum (Fig. 4,a). Transition of an atom soliton curvature on structural levels at the bifurcation sets short-range order displacements are characterized by their own local non-equilibrium Gibbs potential [9], Causing the appearance of a local minimum of the curve F (v).

This causes metastability deformation defects of all types. The consequence of this is the possibility of the coexistence of a wide range of structural states (Fig. 2). When martensitic transformations induced deformation may exist martensitic phases with different structures. Thus, in Fig. 2 for processing cryomechanical alloy thin film Fe-Mn-C austenite is transformed into martensite. He may have not only traditionally known BCC structure, but also the structure of the type Frank-Kasper FK12, FK14 and FK16 (Fig. 2, d).

FK16 structure received after laser irradiation of a thining foil $\mathrm{Fe}_{86} \mathrm{Mn}_{13} \mathrm{C}$ alloy. This X-ray diffraction pattern presents on Fig. 3,c. To identify the diffraction pattern shown Fig. 3,c we used a typical X-ray diffraction picture of compound $\mathrm{CaCu} 5$, having a structure of FK16 (ASTM tables). 


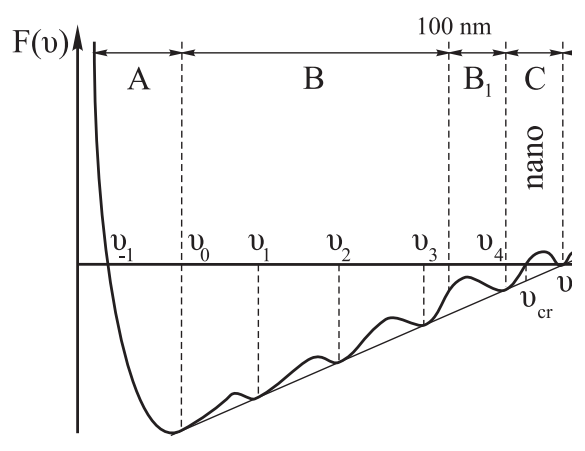

a

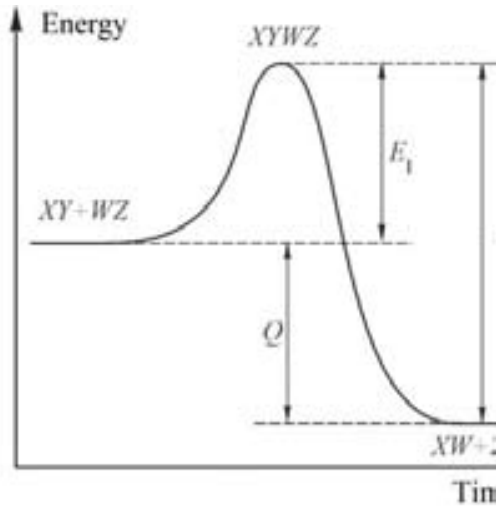

b

Fig. 4. Energy diagrams state of material subjected to plastic deformation: a - dependence of thermodynamic potential of Gibbs F (v) from the molar volume and taking into account local bands of a hydrostatic tension of various gauge in which been arise the defective structures. Fields of various states: A - hydrostatic squeezing; B - mesosubstructures of various gauges; B1 - nanoscale structures; C - nanostructures states; D - porosity and fracture occurrence [3]; b - potential barrier at mechanochemical reactions, $\mathrm{XY}+\mathrm{WZ}$ initial state connected atoms $\mathrm{X}, \mathrm{Y}, \mathrm{W}, \mathrm{Z}$. The state of excited atoms XYWZ and final state with a new structure and new connections $\mathrm{XW}+\mathrm{ZY}[10]$

Fig. 4,b. illustrates the change in the energy of the system as a result of the plastic deformation. The release of energy leads to the excitation of self-propagating high-temperature synthesis in multilayer thin films structures. XY+WZ - the chemical bonds XY and WZ before the plastic deformation. When atoms are shuffled in and out of the equilibrium position, then begin to move freely with energy higher than the energy of the potential barrier. The emitted energy $\mathrm{E} 2-\mathrm{E} 1=\mathrm{Q}$ ensures continuity of the process. Thus atoms move at a speed of about several $\mathrm{km} / \mathrm{s}$.

Any excess of the yield stress generates a wave of plastic deformation [8]. Wave of plastic deformation consists of one longitudinal and two transverse modes so any shift creates turn. Such rotation is facilitated if the state of the solid becomes a liquid-like, according to the work of [11]. In the wave structure of matter corresponds to irreversible changes in the liquid phase.

Modular organization is the result of cooperative displacements of atomic groups (clusters). An example of such clusters can be packed structure which is represented as a face-centered cubic cell (Fig. 5,a). It consists of an octahedron surrounded eighth tetrahedral.

According Shal'nikov [12] liquid-like metallic phase consists of clusters if the system temperature is above $4 \mathrm{~K}$.

We have proposed decoding scheme similar electron diffraction using modular design elements proposed in [13]. Assembled according to the electron diffraction pattern cluster is shown in Fig. 5, ab [14]. It consists of three modules FCC lattice connected to the nucleus in the center of the tetrahedral (see Fig. 5,b). The plane (110) FCC coincides with the plane of the drawing. The scheme shows that in such a modular assembly of the vector [111] of the 1st module is almost parallel to the vector [002] of the 3rd module, etc. Each module of the FCC lattice consists of two tetrahedral and one octahedron (indicated in gray). Vectors [111] and [200] relating to the modules of different groups are parallel to each other. It is impossible to implement in a cubic crystal, but is easily 


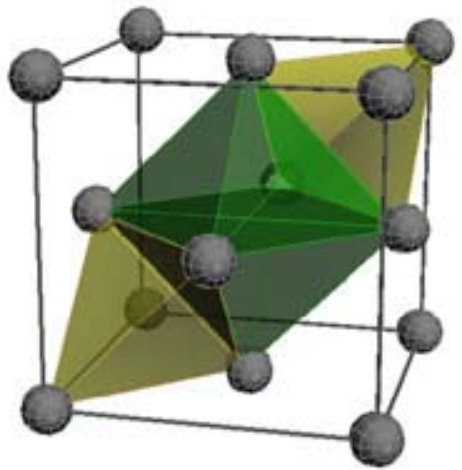

a

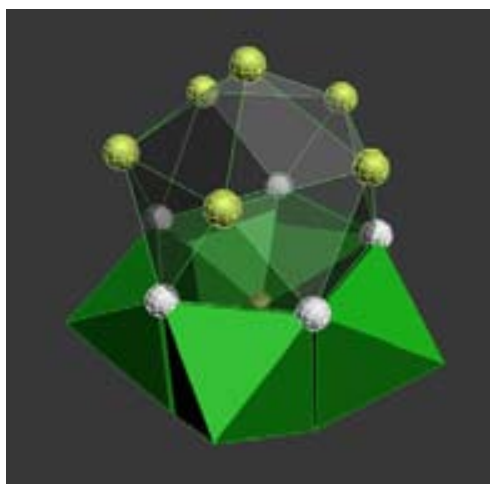

$\mathrm{c}$

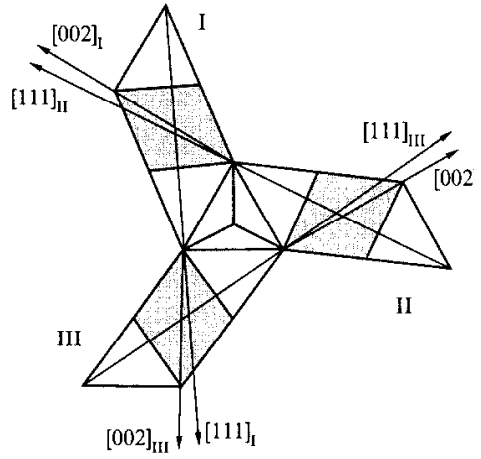

b

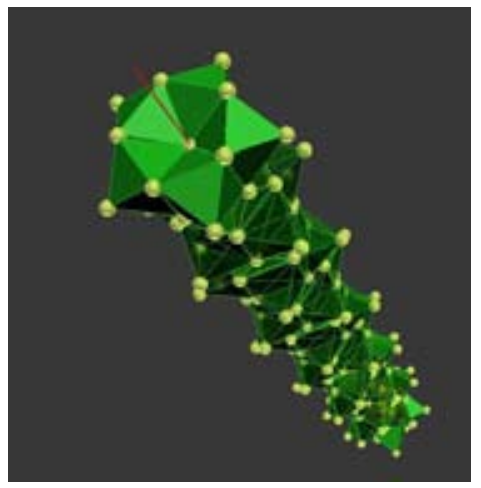

d

Fig. 5. The clusters structure models: $a$ - FCC austenite initial state; $b$ - the formation of clusters FK12 martensite structure. Three sectional FCC cube by diagonal plane type 110. The center triangle is projection tetrahedral clusters of fcc-lattice [14]; c - cluster assembly consisting of icosahedra (FK12) and five octahedral (fragment of string propagation); $\mathrm{d}$ - the propagation strings deformation martensite

implemented in a modular assembly, the center of which is tetrahedral close-packed cluster. Such modular assembly percolation way fill the space.

The modeling of deformation martensite obtained by combination of icosahedrons (FK 12) and octahedrons. Icosahedron is a polyhedron with tetrahedral close-packed structure Frank-Kasper FK12. On Fig. 5,c the initial cluster (consists of five octahedra and icosahedron) is shown. On Fig. 5.d the cluster expanded with new icosahedron and octahedron is shown.

In thin film alloy samples Fe86Mn13C, subjected cryomechanical processing observed optical transitions. In Fig. 4.1 shows the spectra of the optical absorption alloy film $\mathrm{Fe}_{86} \mathrm{Mn}_{13} \mathrm{C}$ before (lower spectrum) and after (upper spectrum) cryomechanical processing. The spectrum obtained from the film after cryomechanical processing includes sharp peaks, in contrast to the initial state of the film. We see five distinct reflections at certain wavelengths.

In Fig. 6,b shows the calculated spin-polarized electronic density of states by the scattered waves Slater fragment for clusters FK 12 connected with 5 octahedrons (fragment of string propagation), simulated by the method of Slater theory of the scattered waves. Combined density of states for spin "up" and "down" reveals the following feature: the Fermi level (EF $=-0.807 \mathrm{Ry})$ falls in the region, which is characterized by a large gap in energy for spin "down" and "gap" spins "up" . This shows 


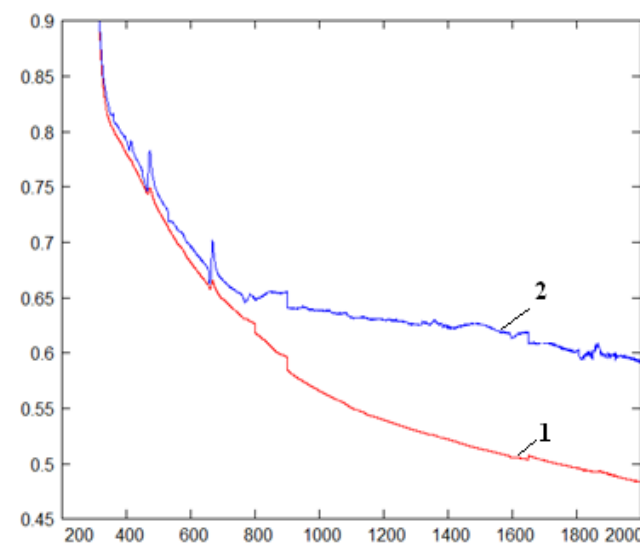

a

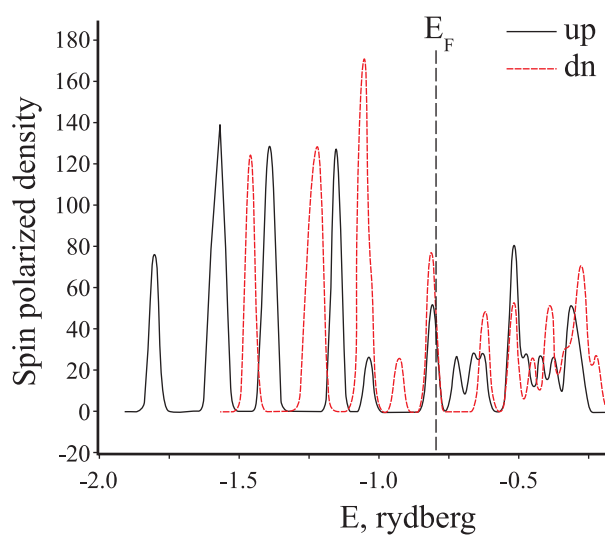

b

Fig. 6. The comparing energy of the optical transitions with energy obtained from the calculation of the spinpolarized electron density of states for FK 12 connected with 5 octahedrons: a - optical absorption of the film Fe86Mn13C: 1 - before 2 - after cryomechanical processing, the absorption spectrum containes lines which probably are the result of exciton absorption; $b$ - spin polarized density of electronic states for clusters FK 12 connected with 5 octahedrons (fragment of string propagation)

that the electron mobility for the type of structure can be limited, and this leads to the possibility of semiconducting properties.

\section{Conclusion}

In this paper, self-assembly phenomena experimentally observed crystal and magnetic structure at different levels of scale. Experimental results are compared with the concept of self-assembly structure in a solid state subjected to plastic deformation. This conception was offered in the works V.E. Panin with employees.

Nature thermoelectric and magnetoresistive properties can be related to the heterogeneity of the phase composition formed in martensitic transformations.

Comparing the energy of the optical transitions obtained experimentally with the calculated data for the energy gaps of the electronic states with spin "up" and spin "down" for a cluster - track rod prorpstaniya come to the conclusion that they are very well coincide with the approach of the order of 0.001 P. Consequently, This theory is well confirmed by experiment, that can serve as proof of the existence of so-called rods sprouting in the alloy samples Fe86Mn13C, kriomehanicheskoy undergoing treatment.

\section{Acknowledgments}

The authors thank to Zhigalov V.S., Kirensky Institute of Physics Russian Academy of Sciences Siberian Branch, V.N. Cherepanov, A.V. Nyavro Tomsk State University for assistance.

This work was supported by a grant № 278 from the Ministry of Science and Education of the Republic Kazakhstan. 


\section{References}

[1] Kaya D.; Lapa P.N., Jayathilaka P. etc. // Journal of Applied Physics, 113, (2013) 17D717.

[2] Panin V.E. // Theoretical and Applied Fracture Mechanics. 2001. Vol. 37. Issues 1-3. P. 261298.

[3] Kandaurova G.S., Ivanov V.E. // Pisma Zh. Eksp. Teor. Fiz. 66, No. 11, (1997) P. 688-692.

[4] Kveglis L.I., Abylkalykova, R.B., Djes, A.V. etc. // Advanced Materials Research, 2014. Vol. 871. P. 226-230.

[5] Kveglis L.I., Abylkalykova R.B.; Noskov F.M. etc. // Superlattices and Microstructures, 2009. V. 46. P. 114-120.

[6] Zlatic V., Monnier R. // Phys. Rev. B. 2005. V. 71. P. 109-165.

[7] Pearson B. The Crystal chemistry and physics of metals and alloys. NewYork: Willey, 1972 (Mir, Moscow, 1977). P. 418.

[8] Panin V.E., Egorushkin V.E. // Physical Mesomechanics, 2013. V. 16. № 4. P. 267-286.

[9] Leontovich M.A. // Zh. Eksp. Teor. Fiz. 1938. V. 8. P. 844-854.

[10] Zel'dovich Y.B., Raiser Y.P. // Physics of Shock Waves and High-Temperature Hydrodynamic Phenomena. Moscow: Fizmatlit, 2008. 656 p.

[11] Golovnev I.F., Golovneva E.I., Merzhievsky I.A., Fomin V.M. // Physical mesomechanics, 2013. Vol. 16. No 4. P. 294-302.

[12] Shal'nikov A.I. // Zh. Eksp. Teor. Fiz., 1940. V. 10. № 3. P. $63-69$.

[13] Bulienkov N.A., Tytik D.L. // Russian Chemical Bulletin, 2001. 50 (1). P. 119.

[14] Kveglis L.I., Jarkov S.M.; Staroverova I.V. // Physics of the Solid State, 2001. Vol. 43. No. 8. P. $1543-1548$. 